\title{
ALASKA GROUND-WATER QUALITY
}

By R.J. Madison, T.J. McElhone, and Chester Zenone

U.S. Geological Survey Open-File Report 87-0712 


\section{DEPARTMENT OF THE INTERIOR \\ DONALD PAUL HODEL, Secretary}

\section{U.S. GEOLOGICAL SURVEY \\ Dallas L. Peck, Director}

For additional information:

Chief Hydrologist

U.S. Geological Survey

407 National Center

Reston, VA 22092
For sale by:

U.S. Geological Survey

Books and Open-File Reports Section Federal Center

Box 25425

Denver, Colorado 80225

Use of trade names in this report is for descriptive purposes only and does not constitute endorsement by the U.S. Geological Survey 


\section{FOREWORD}

This report contains summary information on ground-water quality in one of the 50 States, Puerto Rico, the Virgin Islands, or the Trust Territories of the Pacific Islands, Saipan, Guam, and American Samoa. The material is extracted from the manuscript of the 1986 National Water Summary, and with the exception of the illustrations, which will be reproduced in multi-color in the 1986 National Water Summary, the format and content of this report is identical to the State ground-water-quality descriptions to be published in the 1986 National Water Summary. Release of this information before formal publication in the 1986 National Water Summary permits the earliest access by the public. 
Contents

Ground-Water Quality $\ldots \ldots \ldots \ldots \ldots \ldots \ldots \ldots \ldots \ldots \ldots \ldots \ldots \ldots \ldots \ldots \ldots \ldots \ldots \ldots$

Water-Quality in Principal Aquifers $\ldots \ldots \ldots \ldots \ldots \ldots \ldots \ldots \ldots \ldots \ldots \ldots \ldots \ldots$

Background Water Quality $\ldots \ldots \ldots \ldots \ldots \ldots \ldots \ldots \ldots \ldots \ldots \ldots \ldots \ldots \ldots$

Unconsolidated Aquifers $\ldots \ldots \ldots \ldots \ldots \ldots \ldots \ldots \ldots \ldots \ldots \ldots \ldots \ldots \ldots$

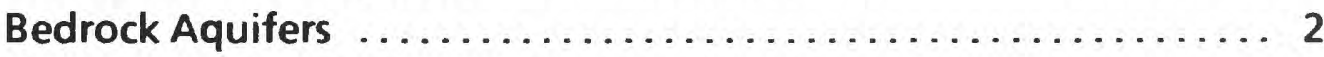

Effects of Land Use on Water Quality $\ldots \ldots \ldots \ldots \ldots \ldots \ldots \ldots \ldots$

Potential for Water-Quality Changes ...................... 3

Ground-Water-Quality Management $\ldots \ldots \ldots \ldots \ldots \ldots \ldots \ldots \ldots \ldots \ldots$

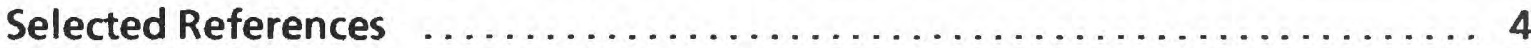

Illustrations

Figure 1.--Selected geographic feature and 1985 population distribution in Alaska.

Figure 2.--Principal aquifers and related water-quality data in Alaska. .....6 6

Figure 3.--Selected waste sites and ground-water quality information in Alaska. ....................................... 7 


\section{Alaska Ground-Water Quality}

In Alaska (fig. 1), about 70 percent of the population obtains water from ground-water sources. About 104,000 of the 276,000 people using ground water ( 38 percent) obtain their supply from privately owned systems (U.S. Geological Survey, 1985, p. 129). Most of the ground water in the major withdrawal areas is suitable for drinking and most other purposes. The median concentration of dissolved solids in most areas does not exceed the State's drinking-water standard of $500 \mathrm{mg} / \mathrm{L}$ (milligrams per liter) (Alaska Department of Environmental Conservation, 1979). Except for water from bedrock in the Fairbanks area, nitrate (as nitrogen) concentrations are considerably smaller than the drinkingwater standard of $10 \mathrm{mg} / \mathrm{L}$ (fig. 2). Objectionable iron and hardness concentrations can occur in most areas; however, these conditions can be improved by using relatively inexpensive treatment systems.

Water quality has been degraded in several areas as the result of septic-system effluents or landfill leachates, but the number of persons affected is small. Contamination of the shallow unconsolidated aquifers (fig. $2 A$ ) by organic contaminants from probable fuel-tank leakage also has been identified at 16 locations. The quality of ground water is naturally impaired in the Fairbanks area, where the concentration of arsenic in water from many wells in bedrock exceeds the State's drinking-water standard of $50 \mu \mathrm{g} / \mathrm{L}$ (micrograms per liter) (fig. $2 B$ ). Concentrations of arsenic as large as $10,000 \mu \mathrm{g} / \mathrm{L}$ have been reported (Johnson and others, 1978).

Alaska has no hazardous-waste sites on the U.S. Environmental Protection Agency's (1986c,d) National Priorities List. However, at 47 military installations in Alaska a total of 193 waste sites had been identified, as of September 1985, by the U.S. Department of Defense (1986) as potential hazardous-waste sites under provisions of the Comprehensive Environmental Response, Compensation, and Liability Act (CERCLA) of 1980. Ninety-two of these sites at 45 military installations (fig. 3) were considered to present a hazard significant enough to warrant response action in accordance with CERCLA. Remedial action at one of these sites has been completed under the program.

The four major sources of potential contamination of aquifers are onsite septic systems, land disposal of wastes, leakage from abandoned fuel tanks, and saltwater intrusion.

\section{WATER QUALITY IN PRINCIPAL AQUIFERS}

Aquifers have been mapped in some detail only in parts of the widely separated major population centers-Fairbanks, Juneau, Anchorage, and Kenai-Soldotna (fig. $1 B$ ). All water-yielding formations in Alaska have been grouped into two principal aquifers (fig. 2A)-unconsolidated alluvium and glacial outwash deposits, and bedrock (U.S. Geological Survey, 1985, p. 129-130). The most extensive development and withdrawal of ground water to date (1986) has been at Anchorage, where more than half of the State's population resides. Two other areas of large-scale ground-water use are the Tanana River valley in interior Alaska, which includes the city of Fairbanks, and a petrochemical industrial complex on the Kenai Peninsula. Nearly all ground-water development in Alaska has been in unconsolidated aquifers. About 1 percent of the State's total ground-water withdrawal is from bedrock.

A data base adequate to describe areal variations in the chemical quality of ground water is available for only a few places, such as Juneau, Kenai, Anchorage, and Fairbanks. Few data have been collected for large areas of the State, and outside of these major population centers, most water-quality data are for the unconsolidated aquifers. Most of the sampled water from the unconsolidated aquifers contains less than $400 \mathrm{mg} / \mathrm{L}$ dissolved solids (fig. $2 B$ ) and is considered to be suitable for most uses. Known concentrations of dissolved solids in ground water range from about $25 \mathrm{mg} / \mathrm{L}$ in stream-channel alluvium to $6,400 \mathrm{mg} / \mathrm{L}$ in shallow wells in some coastal areas. Except in the Fairbanks and Anchorage areas, the bedrock aquifers are virtually undeveloped, and little is known about the quality of the contained water.

\section{BACKGROUND WATER QUALITY}

A graphic summary of selected water-quality variables compiled from the U.S. Geological Survey's National Water Data Storage and Retrieval System (WATSTORE) is presented in figure $2 B$. The summary is based on dissolved-solids, hardness (as calcium carbonate), nitrate (as nitrogen), iron, and arsenic analyses of water samples collected from 1949 to 1976 from the principal aquifers in Alaska. Percentiles of these variables are compared to national standards that specify the maximum concentration or level of a contaminant in drinking-water supply as established by the U.S. Environmental Protection Agency (1986a, b). The primary maximum contaminant level standards are health related and are legally enforceable. The secondary maximum contaminant level standards apply to esthetic qualities and are recommended guidelines. The primary drinking-water standards include a maximum concentration of $10 \mathrm{mg} / \mathrm{L}$ nitrate (as nitrogen) and $50 \mu \mathrm{g} / \mathrm{L}$ arsenic, and the secondary drinking-water standards include maximum concentrations of $500 \mathrm{mg} / \mathrm{L}$ dissolved solids and $300 \mu \mathrm{g} / \mathrm{L}$ iron. For these variables, the State drinking-water standards are the same as the national standards.

\section{Unconsolidated Aquifers}

Most of the sampled water from the unconsolidated aquifers does not exceed the drinking-water standard. Calcium and magnesium, which contribute to the hardness of water, and bicarbonate are the major dissolved ions. In most of the wells, hardness accounts for 60 to 80 percent of the dissolved-solids concentration. In many communities, wells drilled near the coast yield water of sodium bicarbonate or sodium chloride type.

Iron is present in concentrations that exceed drinking-water standards in a large number of shallow wells in most areas of the State. Concentrations larger than $1,000 \mu \mathrm{g} / \mathrm{L}$ are common (fig. $2 B$ ). Iron concentrations larger than about $300 \mu \mathrm{g} / \mathrm{L}$ can cause staining of laundry and plumbing fixtures and can impart a taste to the water.

One of the few areas of Alaska where natural ground-water quality could be considered to be unsuitable for some uses is the Copper River basin (Emery and others, 1985). As a general rule, the ground water becomes more mineralized with increasing depth in the upper Copper River basin. Saline springs in the area are the surface manifestation of saline ground water present in the marine sedimentary rocks that underlie much of the glacial-lake deposits (Grantz and others, 1962). Upward movement of water from these older sedimentary rocks has affected the quality of water in the overlying unconsolidated aquifers. Water in the unconsolidated aquifers is characterized by large concentrations of dissolved solids (as much as $10,000 \mathrm{mg} / \mathrm{L}$ ), sodium, chloride, iron, and manganese.

The summary (fig. $2 B$ ) shows the variability in chemical quality of the water from unconsolidated aquifers for the major areas 
of water withdrawal. For many areas of the State, the number of wells having water-quality information is too small to be adequate for statistical inference. For these areas, a general indication of the range in dissolved-solids concentrations in shallow unconsolidated aquifers can be gained from an analysis of stream water-quality data for low-flow (or base-flow) periods. During winter in interior Alaska, the ground is frozen, no surface runoff occurs, and any streamflow is sustained by ground-water discharge.

Dissolved-solids concentration is considered to be a useful index of overall water quality, but available data do not provide representative coverage for winter streamflow in Alaska. However, specific conductance, which is affected by dissolved-solids content, is a characteristic commonly measured in field water-quality deter-minations. For most natural waters in Alaska, the dissolved-solids concentration ranges from 55 to 65 percent of the specificconductance value. The following table (Zenone and Anderson, 1978) indicates ranges of specific-conductance values measured during base-flow periods for streams in Alaska, except for the southeastern part of the State, where base flow has not been defined.

\section{Summary of specific-conductance values for base flow of streams in Alaska}

[Base-flow period is November 1 to April 30, when surface runoff is small or nonexistent; $\mu \mathrm{S} / \mathrm{cm}$, microsiemens per centimeter at 25 degrees Celsius]

\begin{tabular}{|c|c|}
\hline $\begin{array}{l}\text { Geographic area } \\
\text { (fig. } 1 A \text { ) }\end{array}$ & $\begin{array}{c}\text { Range of specific } \\
\text { Conductance } \\
(\mu \mathrm{S} / \mathrm{cm}), 1949-76\end{array}$ \\
\hline North Slope-n. & $225-350$ \\
\hline 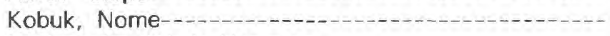 & $150-250$ \\
\hline Kuskokwim, Wade Hampton & $250-300$ \\
\hline Southeast Fairbanks, Upper Yukon, Yukon-Koyukuk--- & $250-400$ \\
\hline Bethel-..... & $100-240$ \\
\hline 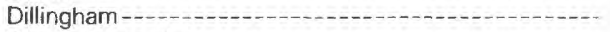 & $50-100^{*}$ \\
\hline Kenai Peninsula & $100-300$ \\
\hline Valdez-Copper River & $300-500$ \\
\hline
\end{tabular}

-Affected by significant volume of lake storage.

In coastal areas of Alaska, the natural ground-water quality can be affected by saltwater intrusion. Coastal aquifers that contain freshwater may be hydraulically connected to the ocean or other saline-water bodies. Under natural conditions, the direction of ground-water flow generally is toward the coast. If pumping lowers the water table or potentiometric surface so that the natural gradient is reversed, saline water will move into the freshwater aquifer. Increases in salinity of the water resulting from pumping stress on the aquifer have occurred at Indian Cove, a small community near Juneau. Six of 18 wells currently in use there produce brackish water having dissolved-solids concentrations larger than $1,000 \mathrm{mg} / \mathrm{L}$ (Dearborn, 1985).

In island settings and on offshore bars and spits, fresh ground water generally occurs as an unconfined, lens-shaped body floating on saline ground water. Theoretically, in this situation, there is a 40-foot-thick zone of fresh ground water below sea level for each foot of water-table altitude above sea level (Todd, 1980, p. 496). This situation exists at St. George Island, in the Pribilof Islands in the Bering Sea (Anderson, 1976), and at Fire Island near Anchorage (A.J. Feulner, U.S. Geological Survey, written commun., 1964). Other areas where fresh ground water probably occurs only as thin lenses above salty water are at Unalakleet, Kotzebue, and the coastal fringes of the Yukon and Kuskokwim River deltas in western Alaska.

The role of permafrost in directly imparting a particular type of mineralization to ground water is probably minor. A decrease in the rate of ground-water movement by permafrost provides a longer time for reactions between the water and the enclosing rocks than in regions without permafrost (Williams and van Everdingen,
1973). Chemical reaction rates and saturation concentrations of some constituents also are affected by low water temperatures. Ground water beneath permafrost usually is of nearly constant quality at a particular site, although it may differ in composition from one area to another.

\section{Bedrock Aquifers}

Because the bedrock aquifers in most areas of Alaska are undeveloped, very little is known about their water quality. In general, the concentration of dissolved solids in water from bedrock aquifers is larger than that present in the unconsolidated aquifers and the chemical quality is more variable.

One of the areas of more intensive development of bedrock aquifers is in fractured schist of the uplands near Fairbanks. The chemical composition of the water in the schist is extremely variable, and in many instances the presence of large concentrations of several constituents renders the water unsuitable or marginal for domestic use (fig. $2 B$ ). The hardness of ground water from sampled wells in the Fairbanks area ranges from 17 to $1,000 \mathrm{mg} / \mathrm{L}$, and more than 50 percent of sampled wells have a hardness larger than $300 \mathrm{mg} / \mathrm{L}$ (Johnson and others, 1978). Only 7 percent of the sampled wells have a hardness concentration less than $100 \mathrm{mg} / \mathrm{L}$, a level not considered to be objectionable for most uses. Concentrations of iron also are generally large in the Fairbanks area (fig. $2 B$ ).

Arsenic and nitrate concentrations that exceed the drinkingwater standards are common in water from wells completed in the bedrock aquifers near Fairbanks. The primary source of these constituents and the mechanism by which they enter the ground water have not been conclusively demonstrated, but they are considered to be most likely natural (Johnson and others, 1978). For most wells sampled, arsenic concentrations range from 0 to $10,000 \mu \mathrm{g} / \mathrm{L}$. In most bedrock wells, nitrate concentrations are smaller than $10 \mathrm{mg} / \mathrm{L}$ as nitrogen, but water from 21 percent of wells sampled exceeds this value.

\section{EFFECTS OF LAND USE ON WATER QUALITY}

In most of Alaska, ground water is an untapped resource that has been virtually unaffected by humans. However, in the major urban areas and in some outlying villages, ground-water quality has been locally degraded, primarily due to seepage from septic systems, landfills, and abandonded fuel-storage tanks. Sites where ground-water contamination has been documented are shown in figure 3 .

The rapid growth of population in the Anchorage area has resulted in the construction of many large residential developments outside the city's water- and wastewater-system boundaries. These developments use onsite water sources and wastewater-disposal systems. In many areas, subdivision lots of one-half acre or less are served by individual wells and septic systems. The number of operating septic disposal systems in the greater Anchorage area is about 9,000 , or about one for every eight residences. Local contamination of ground water has been caused by septic-system effluent in several areas of Anchorage and Fairbanks. Also, some private water supplies have been contaminated by drainage of surface water into wells that either were improperly constructed or had damaged casing at the ground surface.

Ground water has been contaminated locally in the Anchorage area by the disposal of solid waste directly into lakes that are connected hydraulically to the ground-water system, or by surface disposal in landfills where the water table is shallow (Zenone and others, 1975). Shallow ground water beneath the Merrill Field landfill in Anchorage and the old Greater Anchorage Area Borough landfill (closed since 1977), where near-surface materials are saturated, is severely contaminated by leachate produced within the refuse. Leachate at these two sites is characterized by large concentrations of organic carbon, iron, and manganese, combined with concen- 
trations of dissolved solids ranging from 2 to 20 times greater than adjacent, unaffected ground water.

In addition to bacterial and other contamination from septic systems, and the naturally occurring large concentrations of arsenic and nitrate in the Fairbanks area, a significant ground-watercontamination problem in Alaska is leakage from underground fuelstorage tanks. The rapid population growth in Alaska subsequent to the discovery of petroleum at Prudhoe Bay resulted in the development and conversion of large tracts of land surrounding the major urban centers, from rural homestead areas to suburban communities. Before this development, many rural residents relied on individual buried storage tanks for their home and auto fuel supplies. As other fuel sources became available or when rural residents migrated to newly constructed subdivisions, many of these storage tanks were abandoned. In addition, the expansion and widening of the State's highway system have caused the displacement or relocation of commercial service centers and subsequent abandonment of their fuelstorage facilities. Because suburban development is taking place in the same locations, the potential for degradation of aquifers from leaking fuel tanks is a major concern. Leakage from underground fuel tanks has contaminated aquifers locally in the Nome, Minto, Fairbanks, Anchorage, and Soldotna areas (fig. 3B).

The largest area of aquifer contamination from possible fueltank leakage identified to date (1986) is near Peters Creek, a small suburban community northwest of Anchorage. In April 1986, concentrations of benzene that exceeded the State's drinking-water standards were found in 15 privately owned wells in a Peters Creek subdivision. Significant concentrations of toluene and xylene also were detected in these wells. The delineated zone of aquifer contamination encompasses an area of about 40 individual residence lots. Organic compounds indicative of diesel or gasoline fuels were detected in ground water at several other locations (fig. 3B) throughout the State (Henry Friedman, Alaska Department of Environmental Conservation, written commun., 1986).

To date (1986), neither the State nor the Federal government has had a systematic statewide monitoring program to detect organic contaminants in ground water. The number of wells or aquifers that may be contaminated as the result of fuel-tank leakage presently is unknown. However, because of the many tanks in the ground, especially in rural Alaska, the number of wells affected could be significant.

\section{Potential for Water-Quality Changes}

For large areas of Alaska, minimal information is available on the quality of ground water. The instances of ground-water contamination reported here probably represent the major types of contamination that are most likely to occur, but the extent of aquifers affected presently is unknown.

The potential for increase in ground-water contamination from improperly constructed or failing septic disposal systems is relatively large. Of the approximately 9,000 septic systems in the Anchorage area, many have been installed in the last 10 years. As the efficiency of these systems decreases with age, the possibility exists for an increase in the volume of inadequately treated effluent reaching the shallow ground water.

A large but currently unknown number of old landfills and dump sites exists throughout the State. Many of these sites are the result of construction activities or military operations during World War II, and, in most instances, the type of materials they contain is unknown. These sites are a potential source of contamination.

Under Phase I of its Installation Restoration Program, the U.S. Department of Defense (1986, p. 28-30) has evaluated 193 waste-disposal sites at 47 military installations in Alaska to determine their potential for contamination (fig. $3 A$ ). In Phase-II studies, which are similar to the remedial investigations of the CERCLA process, 92 sites at 45 military installations were considered to present a hazard significant enough to warrant response action. Investigations at these sites are now being completed and either no contamination has been detected or assessment data are being evaluated (U.S. Department of Defense, 1986, p. 28-30); remedial action has been completed at one site.

Ground-water quality beneath or adjacent to municipal landfills (fig. $3 C$ ) outside the Anchorage and Fairbanks urban areas is unknown. Solid-waste disposal in areas of permafrost is, in effect, a storage of material from which a contaminating leachate could be produced if the frozen mass of waste and adjacent permafrost were to be naturally or artificially thawed (Straughn, 1972).

The practice of using lagoons for wastewater disposal and treatment at remote constraction camps and villages throughout Alaska is a potential source of contamination for ground-water supplies. Some of these lagoons are near shallow water-supply wells and infiltration galleries. The lagoons function as sources of local ground-water recharge, and successful operation of the wells and galleries may depend on the permeability and porosity of the same small body of unfrozen material that is recharged by the lagoons.

Accidental oil or fuel spills that occur during major construction projects, and disposal of petrochemical wastes, oil-field brines, and drilling muds are other potential sources of contamination of ground water. Also, leaks from underground fuel storage tanks may increase contamination, because many such tanks exist and may soon reach their design lifetime.

All major population centers except Fairbanks lie partly in coastal areas. Imminent development of Alaska's offshore petroleum and other resources will ensure that future growth and water demand will be concentrated in coastal areas. Additional development of ground-water supplies in those areas will require consideration of the potential for saltwater intrusion.

In the Copper River basin, saline water is pumped from wells and issues from several springs. The connate origin of the saline water has been confirmed by exploratory drill holes (Williams, 1970). Dissolved-solids concentrations of these waters range from 760 to $53,000 \mathrm{mg} / \mathrm{L}$. The potential exists for degradation of the shallow fresh (or at least brackish) water, should excessive pumping cause saline water to migrate or leak upward through the confining beds (Emery and others, 1985).

\section{GROUND-WATER-QUALITY MANAGEMENT}

Alaska Statutes Title 46, Chapter 3 (1971), adopts a policy to "conserve, improve, and protect public health and safety, terrestrial and aquatic life, natural resources, and the environment." To implement the policy, authority to adopt water-quality and pollution-control standards was given to the Alaska Department of Environmental Conservation (DEC). Alaska's water-quality standards, established in Title 18, Chapter 70 of Alaska Administrative Code (1984), apply to all water including ground water, and are used primarily as a basis for establishing conditions in wastewaterdischarge permits issued by the DEC; developing best management practices to control nonpoint sources of pollution; determining the effect of human activities on identified uses of the water; and enforcing actions against operations that adversely affect water quality.

In applying the water-quality standards, the Alaska DEC samples and analyzes State waters, associated plant and animal life, and wastewater discharges. The DEC also requires dischargers to analyze wastewater effluent and receiving waters to assist in protecting water quality. Under the State Drinking-Water Act (Alaska Department of Environmental Conservation, 1979), operators of community water systems are required to monitor water supplies periodically for conformance to State standards.

The DEC is authorized under Title 46, Chapter 3 (1971), to manage hazardous-waste and solid-waste programs. The State has a federally approved solid-waste-management program and has been delegated full authority for solid-waste management under subtitle 
D of the Federal Resource Conservation and Recovery Act (RCRA) of 1976. Authority for hazardous-waste management has not yet (October 1986) been delegated and currently is administered by the U.S. Environmental Protection Agency. Current State statutes authorize the development of regulations that are in conformance with RCRA, and routine ground-water monitoring is required at all land disposal facilities that serve more than 2,000 people or receive 5 tons or more of waste per day. Monitoring requirements generally are limited to those contaminants in the standards that are appropriate and practical for a particular discharger. Ground water is of primary concern to the State in granting land-disposal permits, and a significant part of RCRA grant funds will be directed toward ground water.

Several short-term (3-5 years) networks for monitoring ground-water quality currently are operated by the U.S. Geological Survey in cooperation with the Municipality of Anchorage, the Fairbanks-North Star Borough, and the Matanuska-Susitna Borough. The primary objective of these networks is to monitor potential contamination from landfills ( 25 wells) and areas of septic disposal systems (35 wells). The State does not currently (1986) have a program of ground-water classification or statewide groundwater-quality monitoring. The Alaska DEC samples water-supply wells as a part of special studies or in response to reported or suspected instances of water contamination.

As of 1986 only a small fraction of Alaska's ground water has actually been assessed. The fact that so little is known about ground-water quality, or about the extent of actual or potential contamination, is a function of the large size of the State and the limited staff assigned to ground-water-quality protection. Also, State agencies have been in existence for a relatively short time and, therefore, have had limited opportunity to establish a comprehensive data base. The present level of geologic and hydrologic information for the major aquifer systems in most of Alaska is inadequate to provide for sound management decisions or ground-water protection. To provide for future management of Alaska's ground-water resources, additional information is needed on the existing quality of water and on the location, types, and potential severity of groundwater contamination.

The Alaska DEC presently (1986) is in the initial stages of developing a coordinated statewide ground-water-quality protection program in conformance with guidelines of the U.S. Environmental Protection Agency. As a part of this program, DEC has contracted with the Alaska Department of Natural Resources to inventory the availability of ground-water-quality data in Alaska, and to inventory sites of known ground-water contamination (William Ashton, Alaska Department of Environmental Conservation, written commun., 1986). The results of the assessment (scheduled to be completed in early 1989) will provide an improved data base for developing a comprehensive ground-water-quality management program for Alaska.

\section{SELECTED REFERENCES}

Alaska Department of Environmental Conservation, 1979, Water quality standards: Alaska Department of Environmental Conservation, Alaska Water Pollution Control Program, 34 p.
Anderson, G.S., 1976, Water-resources reconnaissance of St. George Island, Pribilof Islands, Alaska: U.S. Geological Survey Water-Resources Investigations 6-76, $15 \mathrm{p}$.

Dearborn, L.L., 1985, Preferential saltwater intrusion into the metamorphic rock aquifer at Indian Cove, Southeast Alaska, in Dwight, L.P., Chairman, 1985, Resolving Alaska's water resources conflicts: American Water Resources Association, Alaska Section; Institute of Water Resources/Engineering Experiment Station, University of Alaska-Fairbanks Proceedings, p. 151-166.

Emery, P.A., Jones, S.H., and Glass, R.L., 1985, Water resources of the Copper River basin, Alaska: U.S. Geological Survey Hydrologic Investigations Atlas HA-686, 3 maps.

Grantz, Arthur, White, D.E., Whitehead, H.C., and Tagg, A.R., 1962, Saline springs, Copper River lowland, Alaska: American Association of Petroleum Geologists Bulletin, v. 46, no. 11, p. 1990-2002.

Johnson, Paula, Wilcox, D.E., Morgan, W.D., Merto, Josephine, and McFadden, Ruth, 1978, Arsenic, nitrate, iron, and hardness in ground water, Fairbanks area, Alaska: U.S. Geological Survey Open-File Report 78-1034, 2 maps.

Straughn, R.O., 1972, The sanitary landfill in the sub-Arctic: Arctic, v. 25 , no. 1, p. $40-48$.

Todd, D.K., 1980, Ground-water hydrology (2d ed.): New York, John Wiley, 535 p.

U.S. Department of Defense, 1986, Status of the Department of Defense Installation Restoration Program: Washington, D.C., Office of the Assistant Secretary of Defense (Acquisition and Logistics), 35 p.

U.S. Environmental Protection Agency, 1986a, Maximum contaminant levels (subpart B of part 141, National interim primary drinking-water regulations): U.S. Code of Federal Regulations, Title 40, Parts 100 to 149 , revised as of July 1,1986, p. 524-528.

1986b, Secondary maximum contaminant levels (section 143.3 of part 143, National secondary drinking-water regulations): U.S. Code of Federal Regulations, Title 40, Parts 100 to 149 , revised as of July 1,1986 , p. $587-590$.

1986c. Amendment to National Oil and Hazardous Substances Contingency Plan; national priorities list, final rule and proposed rule: Federal Register, v. 51, no. 111, June 10, 1986, p. 21053-21112. 1986d, National priorities list fact book-June 1986: U.S. Environmental Protection Agency, Office of Emergency and Remedial Response, report HW-7.3, 94 p.

U.S. Geological Survey, 1984, National water summary 1983-Hydrologic events and issues: U.S. Geological Survey Water-Supply Paper 2250, 243 p.

1985, National water summary 1984-Hydrologic events, selected water-quality trends, and ground-water resources: U.S. Geological Survey Water-Supply Paper 2275, 467 p.

1986, National water summary 1985-Hydrologic events and surfacewater resources: U.S. Geological Survey Water-Supply Paper 2300, 506 p.

Williams, J.R., 1970, Ground water in permafrost regions of Alaska: U.S. Geological Survey Professional Paper 696, 83 p.

Williams, J.R., and van Everdingen, R.O., 1973, Ground-water investigations in permafrost regions of North America-A review, in Permafrost, the North American contribution to the Second International Conference, Yakutsk, USSR, July 1973, Proceedings: Washington, D.C. National Academy of Sciences, p. 435-446.

Zenone, Chester, and Anderson, G.S., 1978, Summary appraisals of the Nation's ground-water resources-Alaska: U.S. Geological Survey Professional Paper 813-P, 28 p.

Zenone, Chester, Donaldson, D.E., and Grunwaldt, J.J., 1975, Groundwater quality beneath solid-waste disposal sites at Anchorage, Alaska: Ground Water, v. 13, no. 2, p. 182-190. 


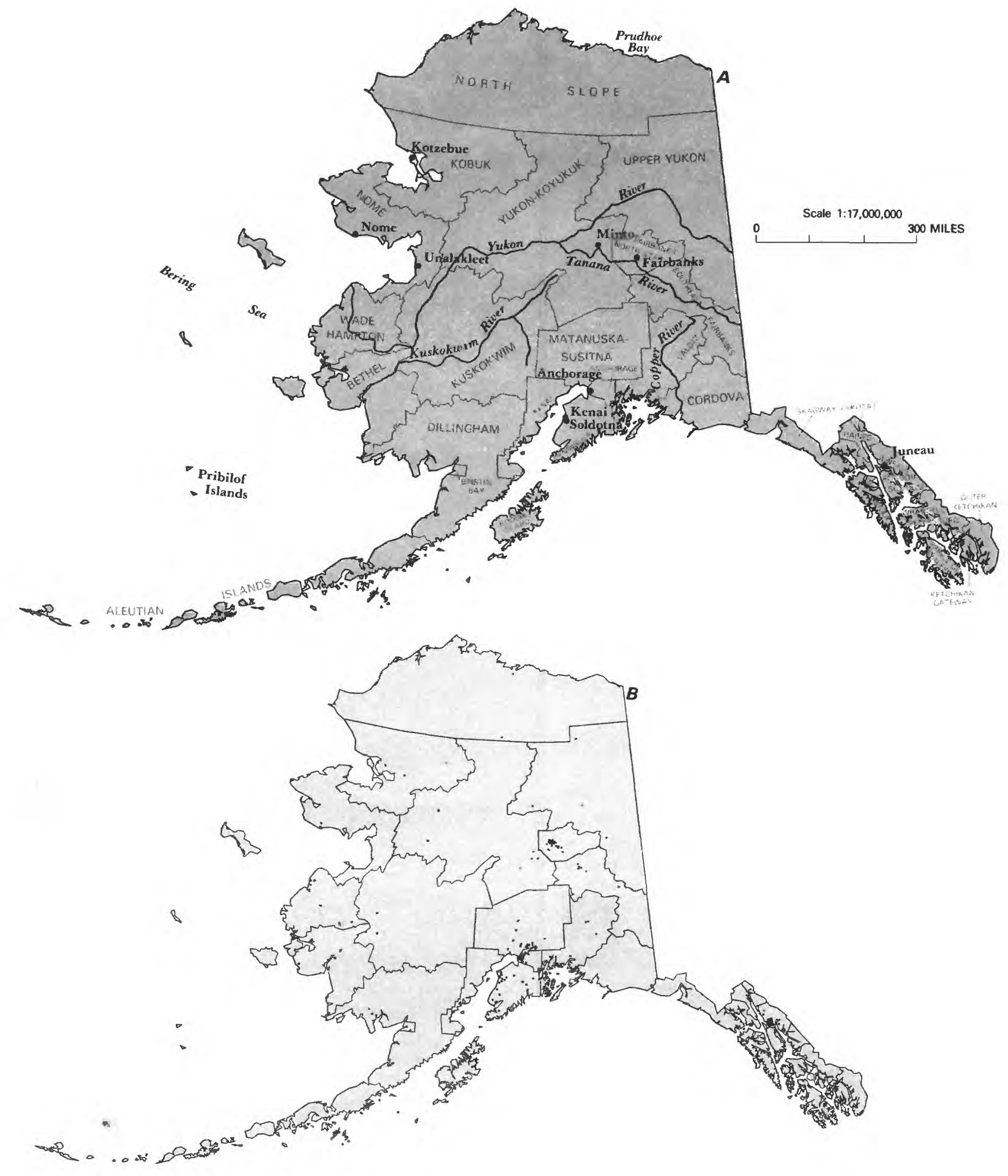

Figure 1. Selected geographic features and 1985 population distribution in Alaska. A, Geographic areas, selected cities, and major drainages. $B$, Population distribution, 1985; each dot on the map represents 1,000 people. (Source: B. Data from U.S. Bureau of the Census 1980 decennial census files, adjusted to the 1985 U.S. Bureau of the Census data for county populations.) 


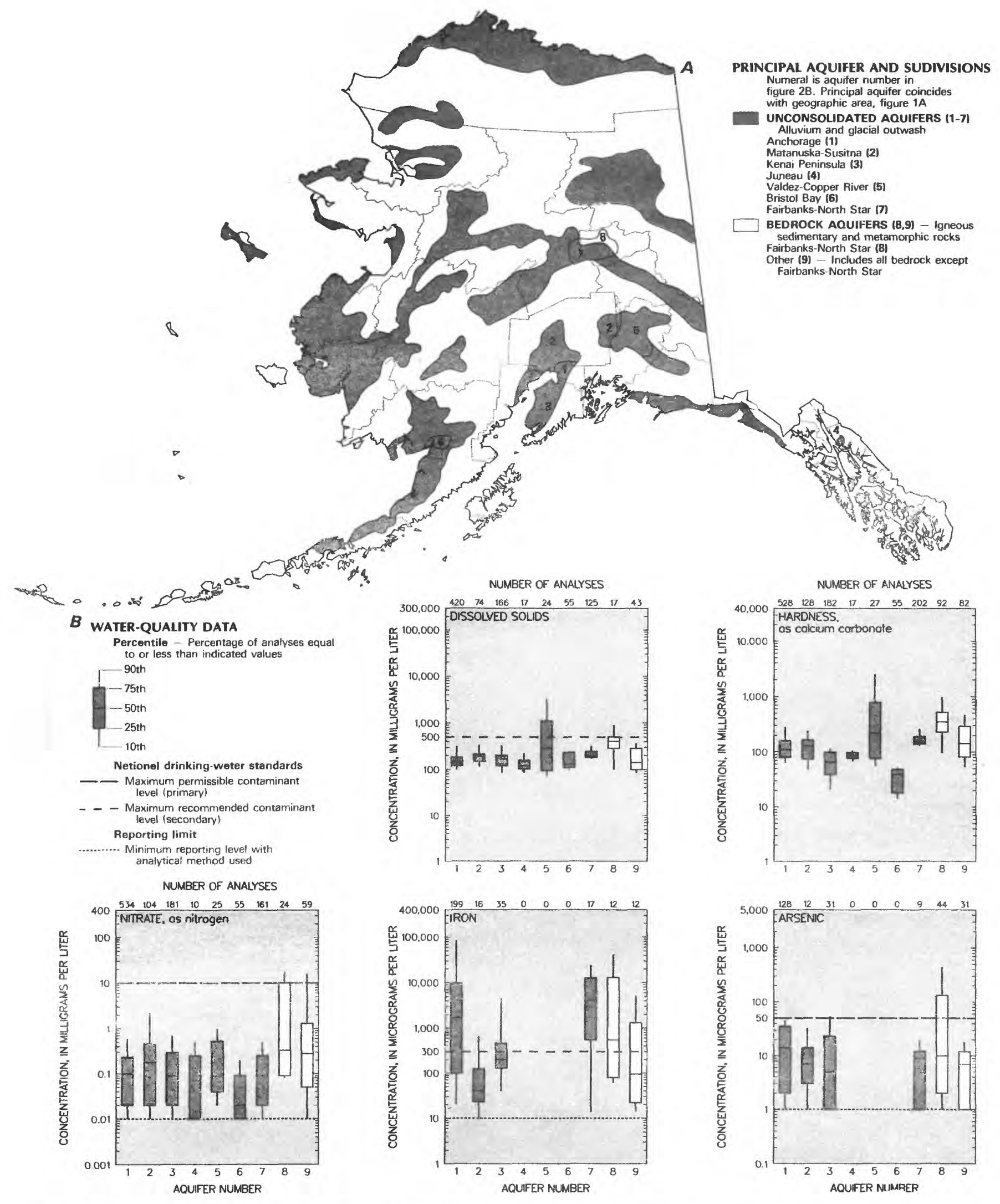

Figure 2. Principal aquifers and related water-quality data in Alaska. $A$, Principal aquifers. $B$, Selected water-quality constituents and properties, as of 1949-86. (Sources: A, U.S. Geological Survey, 1985. B. Analyses compiled from U.S. Geological Survey files; national drinking-water standards from U.S. Environmental Protection Agency, 1986a,b.) 


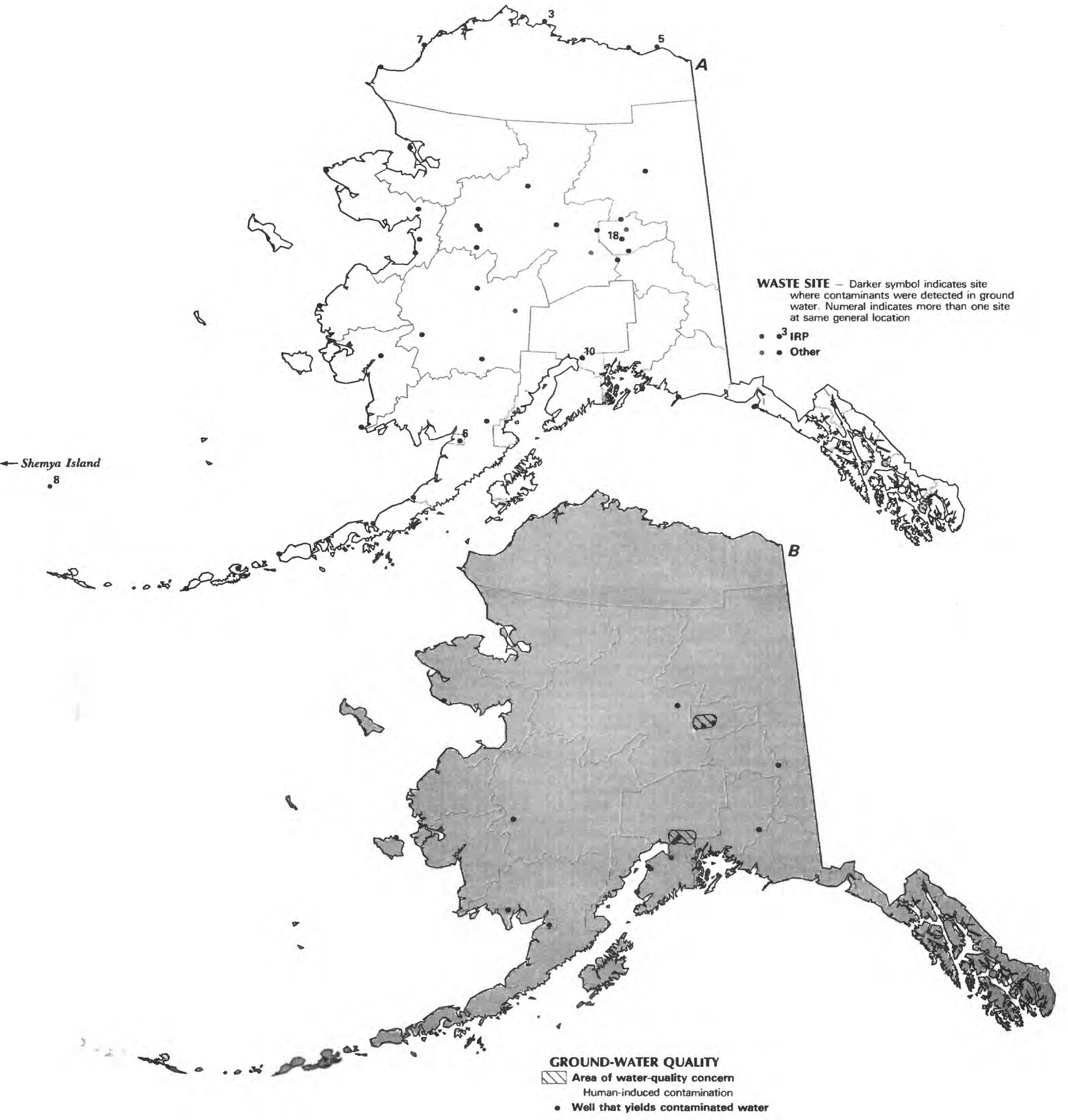

Figure 3. Selected waste sites and ground-water-quality information in Alaska. A, Department of Defense Installation Restoration Program (IRP) sites, as of 1985. B. Areas of human-induced contamination and distribution of wells that yield contaminated water, as of $1986 . C$, Municipal landfills, as of 1986 (Sources: A, U.S. Department of Defense, 1986. B. Alaska Department of Environmental Conservation files, 1986. C. Henry Friedman, Alaska Department of Environmental Conservation, oral commun., July 1986.) 


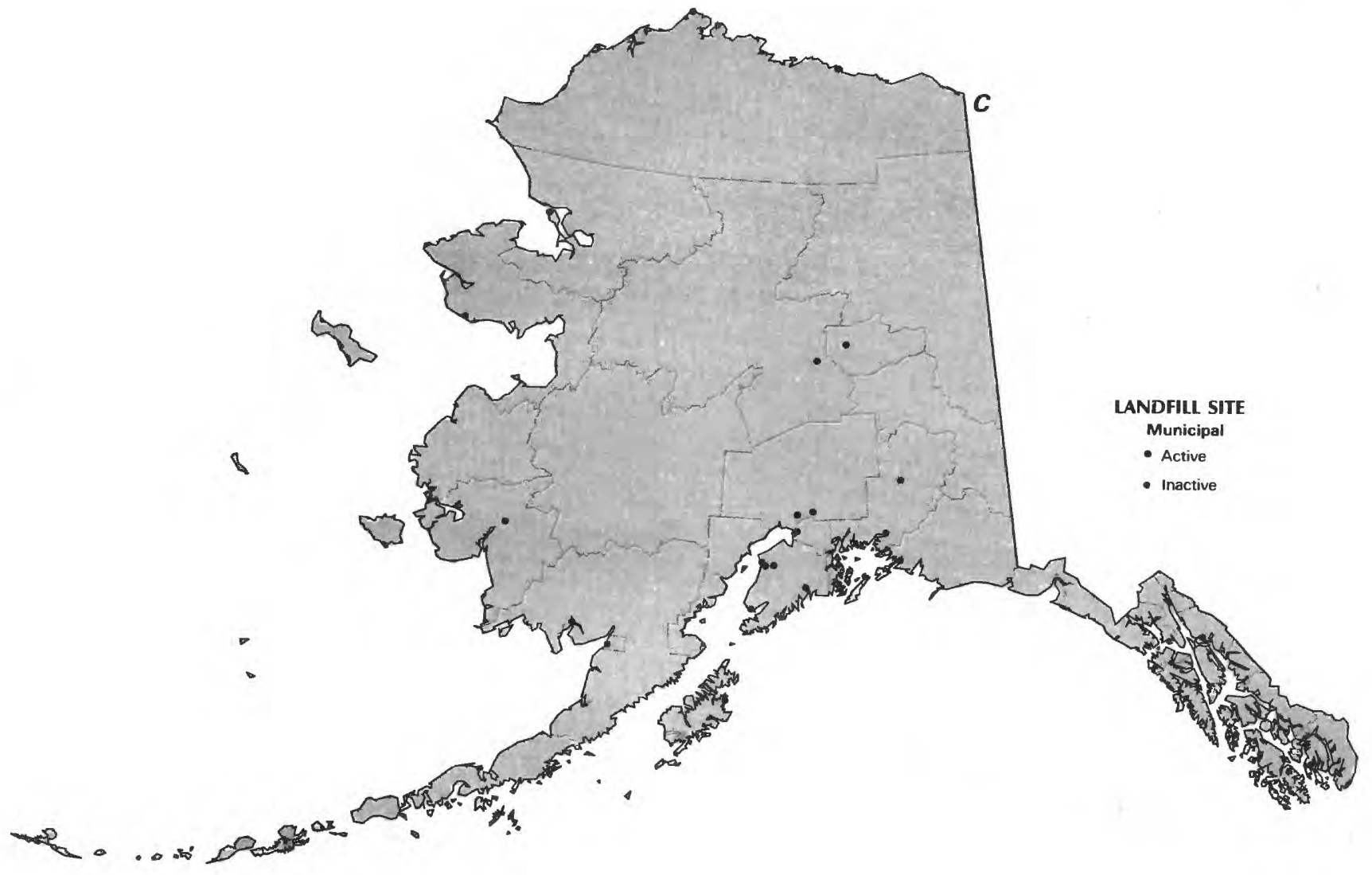

Figure 3.-Continued. 